\title{
VEDAÇÕES VERTICAIS EXTERNAS DO SISTEMA PLATAFORMA DE MADEIRA: MEDIDAS PARA MANUTENÇÃO
}

\section{Candida Pasini Pizzoni, M.Sc. (UFSC) Ângela do Valle, Dra. (UFSC)}

\section{INTRODUÇÃO}

Sabe-se que a degradação prematura das edificações como um todo e de seus elementos, sistemas ou subsistemas, principalmente das vedações verticais externas expostas ao intemperismo, e a consequente redução dos níveis de desempenho da edificação, é um dos problemas enfrentados mundialmente.

A degradação pode ser desencadeada por fatores relacionados à baixa qualidade dos materiais de construção empregados, a falta de um programa de manutenção adequado aos elementos construtivos, a falta de especificação em projeto das características do sis- e operação da edificação, os acabamentos e o desempenho térmico, acústico e lumínico.

Uma das ações preventivas propostas, por exemplo, para a durabilidade das fachadas, está relacionada à estanqueidade do painel parede. Tendo em vista que a madeira, por ser um material de origem biológica, sofre diretamente com a ação da umidade, deformações podem ocorrer no revestimento externo ao longo do tempo e favorecer a entrada de água, prejudicando a estanqueidade da vedação, como mostra a Figura 01.

Figura 01: Deformação nas juntas e exposição do painel à umidade no protótipo Stella-UFSC.

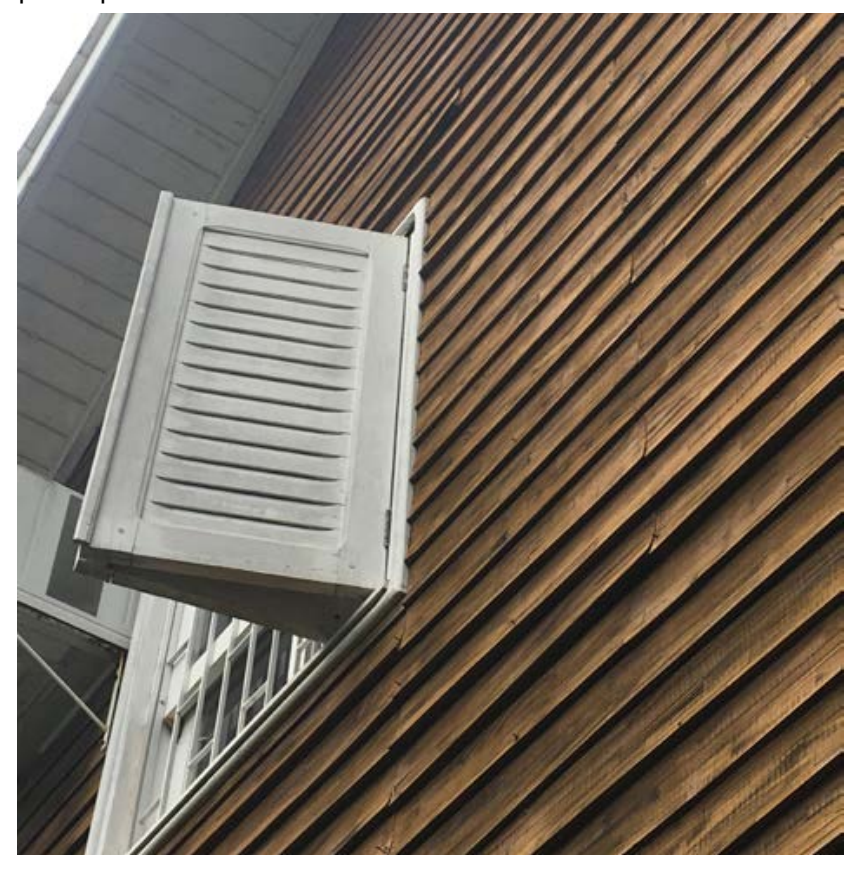

Fonte: Autores

Cabe ao usuário identificar se há deformação, trincas e fissuras ou o acúmulo de água, independente do revestimento utilizado, para que a empresa seja contatada e um profissional habilitado verifique a integridade do revestimento. 
As medidas de manutenção possuem a finalidade de prolongar a vida útil, tornar a edificação durável e proporcionar o desempenho, evitando futuras intervenções que demandem altos custos ou a substituição dos materiais, com a consequente geração de resíduos. A prática de se projetar com enfoque no desempenho, durabilidade e sustentabilidade deve ser incorporada já no processo de projeto da edificação.

\section{REFERÊNCIAS}

POSSAN, E.; DEMOLINER, C. A. Desempenho, durabilidade e vida útil das edificações: abordagem geral. Revista Científica CREA-PR, 1 ed. 2013.

ASSOCIAÇÃO BRASILEIRA DE NORMAS TÉCNICAS, ABNT. NBR 15575: Edifícios Habitacionais de até cinco pavimentos - Parte 4: Sistema de Vedações Verticais externas e internas. Rio de Janeiro, 2013.

INTERNATIONAL ORGANIZATION FOR STANDARDIZATION (ISO). ISO 19208 - Framework for specifying performance in buildings. Suíça, 2016. 